\title{
Małgorzata Lewandowska
}

Uniwersytet Warszawski

\section{Moda, kuchnia i piłka nożna: kreatywność i kultura w nauczaniu języków obcych}

\section{Wstęp}

Austriacki filozof Ludwig Wittgenstein napisał $w$ swoim Tractatus Logico-Philosophicus: „granice mego języka wskazują granice mego świata". Trudno się z tymi słowami nie zgodzić, tym bardziej że w epoce szybkiego Internetu i tanich połączeń lotniczych świat staje się coraz „mniejszy”, a języki obce - coraz ważniejsze. W nauczaniu/uczeniu się języka obcego pomocna może okazać się kultura danego kraju czy obszaru językowego. Jej wartość jest nie do przecenienia po pierwsze ze względu na sam aspekt poznawczy, po drugie zaś dlatego, że kultura stwarza wiele możliwości nauczania/uczenia się języka w sposób kreatywny. Owa kreatywność pozwala uczniom nie tylko przyswoić wiedzę z zakresu języka i kultury, ale sprawia, że nauka staje się ciągłym odkrywaniem oraz dobrą zabawą. Połączenie aspektu kulturowego i ćwiczeń kreatywnych jest jednak istotne także z punktu widzenia motywacji. Bowiem gdy uczenie się jest przyjemnością - po prostu chcemy się uczyć.

Celem niniejszej pracy jest przedstawienie możliwych zastosowań kreatywności $w$ nauczaniu/uczeniu się języków obcych ze szczególnym uwzględnieniem aspektów kulturowych na przykładzie języka i kultury Włoch. Z powodów pragmatycznych, spośród wielu ważnych elementów kultury mieszkańców Półwyspu Apenińskiego wybrano trzy (modę, kuchnię i piłkę nożną). Fakt, że traktuję o kulturze Włoch, nie oznacza jednak, że jedynie o nauczanie/ uczenie się włoskiego tu chodzi. Wręcz przeciwnie, żywię nadzieję, że niniejsza praca stanowić będzie jedynie inspirację i swoisty punkt 
wyjścia do kreatywnego nauczania/uczenia się języka poprzez kulturę nie tylko Włoch, ale również innych krajów. Część praktyczna, prezentująca rozwiązania $w$ postaci ćwiczeń gotowych do zastosowania na zajęciach, zostanie poprzedzona częścią teoretyczną, dzięki której czytelnik będzie miał możliwość zapoznania się z ogólną koncepcją kreatywności w szkole i na zajęciach z języka.

\section{Twórcza edukacja a rola nauczyciela}

Kreatywność rozumiana jako zdolności człowieka do generowania nowych pomysłów czy sposobów działania [Szmidt 2007: 53] powinna być rozwijana przez całe życie. Po pierwsze, dlatego że bycie kreatywnym z całą pewnością przydaje się w wielu sytuacjach życia codziennego. Po drugie, dlatego że na rynku pracy „zapotrzebowanie na specjalistów o twórczych postawach jest coraz większe" [Dobrołowicz, Feder 2002: 36]. Włączenie w proces edukacji zadań pobudzających kreatywność wymaga jednak nowego spojzenia na rolę szkoły, nauczyciela i ucznia. Należy przy tym pamiętać, że termin „twórcza edukacja” (ang. creative education) pojawił się dopiero w 1936 roku [Szmidt 2007: 49] i choć od tego czasu do szkół wprowadzono liczne zmiany w postaci nowatorskich programów nauczania i metod dydaktycznych, to wciąż wiele jest jeszcze do zrobienia.

Często problem braku kreatywności u uczniów (również tych dorosłych) wynika z promowanego w wielu szkołach modelu nauczania/uczenia się. Ów model często narzuca uczniom idealny, podręcznikowy wzorzec oraz sprawia, że zbyt mało operuje się kreatywnym językiem, unika się analogii, porównań i metafor [Necka 2001: 149]. Wyuczone w szkole postawy mogą wpływać negatywnie na naukę języka obcego, a szczególnie na kompetencje produktywne, takie jak pisanie czy mówienie. Postawy twórcze można jednak kształtować, rozwijając jednocześnie kompetencje językowe. Kluczową rolę odgrywa tu oczywiście nauczyciel (lektor języka obcego), który ma być dla uczniów przewodnikiem czy jak to określa Nęcka [2001: 153] - mentorem. 
Nauczyciel odpowiada ponadto za wykreowanie odpowiedniej atmosfery. Mowa tutaj o problem solving classroom [zob. Szmidt 2006: 134-144], czyli takiej klasie, w której wszyscy uczniowie są nastawieni na rozwiązywanie problemów, a odpowiednie pytania są tak samo ważne jak dobre odpowiedzi. Nauczyciel nie powinien stawiać się $w$ pozycji wszechwiedzącego autorytetu. Powinien natomiast dostarczać uczniom problemów do rozwiązania, pełnić rolę trenera oraz obserwatora i moderatora ewentualnych dyskusji [zob. Szmidt 2006: 135].

Istotną kwestią jest również język, jakiego nauczyciel używa w stosunku do uczniów. Okazuje się bowiem, że ma on ogromne znaczenie $w$ procesie kreowania postaw twórczych. Nęcka [1998: 26-28] mówi o idea killers, czyli takich zwrotach językowych, które są "stosowane powszechnie w celu jawnego lub zakamuflowanego krytykowania cudzych pomysłów". Nęcka [tamże] wyróżnia kilka błędów popełnianych przez osoby oceniające pomysły innych. Pierwszy błąd polega na traktowaniu pomysłu jako integralnej, niezróżnicowanej całości („,to zły, głupi, nierealny, itp. pomysł" autor proponuje więc zastąpić komentarzem "w tym pomyśle nie podoba mi się to lub owo"). Niesłuszne jest według badacza również nieuzasadnienie krytyki („wiadomo, że to nie będzie działać”). Nęcka [tamże] poleca też unikanie zwrotów kategorycznych, jak na przykład "to złe" i proponuje zastąpić je sformułowaniami „nie podoba mi się to, że....", „nie rozumiem, dlaczego...".

Problem oceny nie ogranicza się jednak do kwestii samego języka. Ocena kreatywności jest wyjątkowo trudna, tym bardziej że, jak twierdzi Karwowski [2005: 71-72], najlepiej byłoby, gdyby ci, którzy kreatywność oceniają, sami byli ludźmi kreatywnymi. Nauczyciel, którego charakteryzuje postawa twórcza, ma jeszcze jedną zaletę - zna strategie używane do generowania nowych pomysłów. Uczy więc nie tylko języka obcego, ale pokazuje, jak stawiać pytania, oferuje pomoc $w$ momentach zniechęcenia czy zmęczenia, wiedząc, że takie momenty są normalnym elementem procesu twórczego [zob. Starko 2010]. 
Nie ulega wątpliwości, że najlepiej byłoby, gdyby w klasie znajdowali się również uczniowie o osobowościach twórczych, czyli tacy, którzy są otwarci i wrażliwi na problemy, dostrzegają je i potrafią sformułować, umieją zadawać pytania, są gotowi do zmierzenia się z nowymi pomysłami, łatwo się przystosowują do nowych sytuacji, potrafią reagować na zmiany, posiadają zdolność analizowania i syntezowania materiału [zob. np. Dobrołowicz, Feder 2002: 36]. Jednak postawa twórcza nie zawsze ma szanse dojść do głosu. Wynika to z faktu istnienia przeszkód różnie nazywanych przez badaczy (bariery, inhibitory, mental block, conceptual block), których źródłem, jak pisze Dobrołowicz [1993: 196], są „normy i wzory kulturowe, według których funkcjonuje dana społeczność oraz warunki społeczne środowiska życia". Zadaniem nauczyciela, ale także ucznia, jest starać się owe bariery wyeliminować, by zarówno na lekcji, jak i później, w sytuacji życia codziennego, można się było swobodnie komunikować w języku obcym.

\section{Przygotowanie lekcji z ćwiczeniami rozwijającymi kreatywność}

Solidne przygotowanie lekcji to dobra lekcja. Planując poszczególne jej etapy, warto skorzystać ze sprawdzonych schematów [zob. np. Komorowska 2005: 70], pamiętać o takich elementach, jak rozgrzewka językowa na początku lekcji oraz ćwiczenie zamykające na jej koniec. Poleca się stosowanie dość częstej zmienności ćwiczeń ze względu na ograniczony czas i potrzebę rozwijania czterech kompetencji językowych u uczniów.

\section{1. Ćwiczenia klasyczne i ćwiczenia kreatywne}

Wprowadzenie ćwiczeń pobudzających kreatywność nie musi oznaczać rezygnacji z podręcznika oraz klasycznych metod nauczania. Można bowiem skutecznie łączyć ze sobą różne typy ćwiczeń. Należy jednak pamiętać, że to ćwiczenia kreatywne, 
w przeciwieństwie do mechanicznych (których nie sposób wyeliminować przecież całkowicie, zob. Pallotti 2006: 26), zmuszają uczniów do większej aktywności, rozwijają ich fantazję, umiejętność poszukiwania analogii i rozwiązywania problemów.

Wiele z popularnych na zajęciach z języka zadań nie rozwija kreatywności uczniów. Przykładem mogą być klasyczne ćwiczenia, które wymagają od ucznia tylko jednej, prawidłowej, podręcznikowej odpowiedzi. Wstawianie $w$ ramki odpowiednich form gramatycznych, skądinąd bardzo w nauce języka potrzebne, utrwala materiał, ale nie pobudza kreatywności. Kolejnym przykładem są ćwiczenia na słuchanie, które polegają na odsłuchaniu tekstu z taśmy i wpisaniu (znów!) tylko jednej poprawnej odpowiedzi. Testy językowe, niejednokrotnie sprawdzane według klucza, również nie zachęcają do wykorzystania potencjału twórczego i „intelektualnych poszukiwań”. Przykłady można by mnożyć w nieskończoność.

\subsection{Zalety wykorzystania kultury na zajęciach z języka}

Osadzenie języka w kulturze wydaje się nie tylko atrakcyjne, ale również konieczne dla poznania i zrozumienia ludzi, którzy się tym językiem posługują. Język jest bowiem odbiciem kultury i wartości wyznawanych przez jego użytkowników [zob. np. Tokarski 2013: 313-314]. Pominięcie na zajęciach z języka aspektów kulturowych jest więc błędem, tym bardziej że owe aspekty mogą okazać się dodatkowym bodźcem stymulującym motywację. Kto uczy języka obcego, wie, że często miłość uczniów do języka powodowana jest zainteresowaniem kulturą danego kraju. Uczestnicy zajęć z języka włoskiego to niejednokrotnie miłośnicy opery, studenci architektury i sztuki czy amatorzy włoskiej sztuki kulinarnej.

Każdy język daje nieograniczone możliwości wyboru tematów kulturowych na zajęcia kreatywne. Mogą być to tematy często występujące $w$ podręcznikach do nauki języków lub wręcz przeciwnie - ciekawostki kulturowe, o których mało kto słyszał. Wachlarz możliwości jest ogromny. Moda, kuchnia i piłka nożna jako elementy kultury na zajęciach z języka włoskiego pojawiają 
się niemal zawsze. Są one bowiem jednymi z najważniejszych aspektów kultury mieszkańców Półwyspu Apenińskiego [zob. np. Cappolaro-Nowell 2008]. Warto tu zaznaczyć, że oprócz wartości poznawczej, dogłębne poznanie kultury ma jeszcze jedną wartość dla osoby uczącej się języka - poszerzenie słownictwa dotyczącego tematu, na który na pewno przyjdzie jej rozmawiać.

\subsection{Dobór materiału}

Przygotowując lekcję języka włoskiego traktującą o modzie, kuchni lub piłce nożnej, warto pamiętać, że tak jak $w$ przypadku innych tematów, wybór materiału powinien różnić się $w$ zależności od poziomu języka uczniów oraz poziomu ich zainteresowania tematem. W przygotowaniu lekcji pomoże na pewno analiza potrzeb, dzięki której można dowiedzieć się nie tylko, po co dany uczeń uczy się języka, ale także, jakie kompetencje językowe będzie wykorzystywał najczęściej. Warto odkryć, czy na przykład słownictwo związane z modą będzie służyło jedynie do zrobienia we Włoszech zakupów czy też jest uczniowi/uczestnikowi kursu językowego potrzebne do pracy.

Tematy kulturowe mogą okazać się wspaniałym źródłem pomysłów do wykorzystania w ćwiczeniach pobudzających kreatywność. Warto jednak zaznaczyć, że wybór kuchni włoskiej jako tematu wiodącego nie musi oznaczać, że ograniczamy się do pola semantycznego „kuchnia”. Sztuka kulinarna może stanowić doskonały punkt wyjścia do nauczania/uczenia się na przykład konstrukcji gramatycznych, kolokacji i innych zagadnień. Nauczyciel może więc posłużyć się ciekawym tematem kulturowym, by „przemycić” trudny materiał gramatyczny.

Dobrze gdy przygotowując lekcję języka obcego, nauczyciel nie ogranicza się do podręcznika. Ten bowiem często nie jest w stanie zaoferować wystarczającej ilości ćwiczeń rozwijających kreatywność. W dobie ogólnodostępnej prasy zagranicznej i szybkiego Internetu możliwości są nieograniczone i należy z nich korzystać, poszukując przede wszystkim materiałów autentycznych: ulotek, artykułów, wierszy, piosenek, filmików instruktażowych, z takich stron jak Youtube.com, haseł reklamowych, fragmentów filmów itd. 


\section{Kreatywność a kultura Włoch - praktyczne przykłady}

Proponowane poniżej rozwiązania są jedynie wskazówką i powinny być potraktowane jako inspiracja nie tylko dla lektorów języka włoskiego, ale także dla nauczycieli innych języków. Zamieszczone poniżej propozycje są dowodem na to, że rozwijanie kreatywności poprzez kulturę nie jest trudne. Propozycja obejmuje przykłady z rożnych poziomów zaawansowania (od A1 do C2) oraz pomaga rozwijać wszystkie kompetencje językowe.

\subsection{Moda}

Na lekcjach języka włoskiego często porusza się temat mody. Mało jest bowiem na świecie narodowości tak bardzo skoncentrowanych na wyglądzie i tak bardzo kochających modę. Historia mody włoskiej wydaje się nie mniej ważna niż sama historia Włoch. Mediolan od lat utrzymuje pozycję jednej ze stolic światowej mody, włoskie marki - Valentino, Prada, Gucci, Versace, Armani i Dolce \& Gabbana - znane są i cenione na całym świecie, a przyczepiona do ubrania metka made in Italy wszędzie kojarzy się z jakością wykonania. Moda jest również tym tematem, z którym osoba ucząca się włoskiego na pewno spotka się we Włoszech. W opanowaniu niezbędnego materiału pomóc mogą poniższe ćwiczenia.

1) Sfilata di moda (pokaz mody), poziom: B2-C2, indywidualnie, kompetencje: pisanie, czytanie

Cel: powtórzenie słownictwa związanego z modą, rozwijanie kompetencji pisania (recenzja)

Przebieg ćwiczenia: Nauczyciel pokazuje uczniom fragment pokazu mody. Zadaniem uczniów jest napisanie recenzji z obejrzanego pokazu, w której przedstawią trendy na nadchodzący sezon. Na koniec każdy uczeń prezentuje swoją recenzję.

2) Moda nei proverbi (moda w przysłowiach), poziom: B1-C2, w parach, kompetencje: pisanie, mówienie

Cel: powtórzenie słownictwa związanego z modą 
Przebieg ćwiczenia: Nauczyciel prosi uczniów, żeby dobrali się w pary, następnie pisze na tablicy początek kilku przysłów włoskich związanych z ubiorem, przykład: L'abito e il riso manifestano l'uomo (Ubiór i śmiech świadczą o człowieku). W pierwszym etapie nauczyciel podaje uczniom jedynie pierwszą część przysłowia L'abito e il riso ${ }^{1} .$. Zadaniem uczniów jest wymyślić zakończenie tych przysłów i zaprezentować swoje pomysły na forum klasy. $\mathrm{Na}$ koniec zadania nauczyciel rozdaje uczniom kartkę z istniejącymi wersjami przysłów i wyjaśnia ich znaczenie.

3) Vestito ideale (idealny strój), A1-B1, grupy 3-osobowe, kompetencje: czytanie, mówienie

Cel: powtórzenie słownictwa związanego z modą - nazw ubrań i akcesoriów

Przebieg ćwiczenia: Nauczyciel prosi uczniów, żeby podzielili się na grupy. Każdej z grup wręcza karteczkę z wcześniej przygotowanym, krótkim opisem postaci (opis powinien zawierać takie informacje, jak wiek, zawód, miejsce zamieszkania, zainteresowania). Zadaniem uczniów jest wymyślenie dla danej osoby idealnego stroju do pracy, na wieczorne wyjście z przyjaciółmi i do snu. Strój powinien idealnie pasować do charakteru i sposobu życia każdej z postaci. Ćwiczenie jest tym ciekawsze, im ciekawsi są jego bohaterowie. Dlatego też warto, by nauczyciel również wykazał się tutaj kreatywnością. Przykładowymi postaciami mogą być: Królewna Śnieżka (Biancaneve), szalony profesor (un professore pazzo), zakochany Eskimos (un eschimese innamorato), XVI-wieczny podróżnik (un viaggiatore del '500).

\subsection{Kuchnia}

Włosi uwielbiają nie tylko jeść, ale także mówić o jedzeniu. Osoba ucząca się języka włoskiego, rozmawiając z Włochem, ma więc niemal stuprocentową gwarancję zetknięcia się z tematem

1 Słowo il riso w języku włoskim może oznaczać również „ryż”, uczniowie mogą przetłumaczyć je tak jak chcą i wymyślić zupełnie zaskakujące zakończenie przysłowia. 
kuchni i gotowania. Zadaniem nauczyciela jest nie tylko nauczenie słownictwa związanego z tymi tematami, ale także przekazanie najważniejszych zasad związanych z jedzeniem, które znają wszyscy mieszkańcy Italii, a które Polakom sprawiać mogą nie lada problem. Pierwszą nowością mogą okazać się włoskie godziny posiłków, kolejną - zasady ich spożywania, w tym kolejność dań. Zaskoczyć może również fakt jedzenia śniadania w barze, rytualne parzenie kawy czy niezliczone jej rodzaje. Z pomocą przyjść jednak mogą kulturowe ćwiczenia, których przykłady zaprezentowano poniżej. Tak jak w przypadku mody, wykorzystano elementy kulturowe do pobudzenia kreatywności uczniów.

1) Menu all'italiana (włoskie menu), A2-B2, grupy 3-4-osobowe, kompetencje: mówienie

Cel: powtórzenie nazw produktów spożywczych i znanych włoskich producentów jedzenia (Illy, Lavazza, Barilla, Perugina), powtórzenie zasad komponowania włoskiego menu

Potrzebne materiały: gazetki $z$ ofertami włoskich supermarketów

Przebieg ćwiczenia: Nauczyciel prosi uczniów, żeby podzielili się na 3-4-osobowe grupy. Każda z grup musi stworzyć włoskie menu złożone z przystawki (antipasto), pierwszego dania (primo piatto), drugiego dania (secondo piatto), deseru (desert), kawy (caffé) i am-

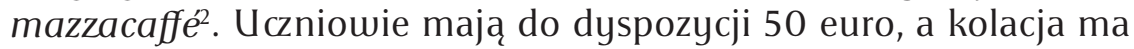
być dla 4 osób i składać się wyłącznie z produktów z gazetek promocyjnych. Obowiązuje limit czasu, np. 20 minut. Na koniec każda z grup prezentuje menu wraz z kosztorysem. Nauczyciel zapisuje na tablicy menu każdej z grup i zaznacza elementy, które zgadzają się (i ewentualnie nie zgadzają) z włoskimi zasadami tworzenia menu i spożywania posiłków. Wskazuje również na elementy brakujące (np. brak kawy) czy weryfikuje dobór wina (np. białe do owoców morza czy ryb, czerwone wytrawne - do dziczyzny).

2) Rosso come un peperone (czerwony jak papryka), A1-A2, indywidualnie/w parach, kompetencje: pisanie, mówienie

2 Odrobina alkoholu wysokoprocentowego pitego na koniec posiłku, po spożyciu kawy. 
Cel: powtórzenie słownictwa związanego z jedzeniem oraz nazw kolorów, wyćwiczenie umiejętności dokonywania porównań

Przebieg ćwiczenia: Nauczyciel pisze na tablicy znane włoskie porównanie: Rosso come un peperone (wł. czerwony jak papryka) i prosi uczniów o utworzenie podobnych porównań z wykorzystaniem znanych im produktów spożywczych oraz kolorów. Po 7-10 minutach nauczyciel zapisuje na tablicy porównania uczniów. $\mathrm{Na}$ koniec kolorową kredą/kolorowym markerem zaznacza te, które we Włoszech używane są zwyczajowo (jeżeli uczniowie je odkryli).

3) Italiano in Polonia (Włoch $w$ Polsce), B2-C2, indywidualne/w parach, kompetencje: pisanie, mówienie

Cel: wyćwiczenie umiejętności definiowania pojęć, powtórzenie słownictwa z zakresu jedzenia i przygotowywania potraw, przygotowanie definicji nieznanych Włochom potraw polskich, które nie raz pomogą polskim studentom wytłumaczyć, co jada się w naszym kraju.

Przebieg ćwiczenia: Nauczyciel prosi uczniów o stworzenie jak najlepszych definicji następujących polskich dań: żurek, bigos, gołąbki, makowiec, pierogi ruskie. Spośród definicji nauczyciel wraz z uczniami wybiera najlepsze i zapisuje je na tablicy.

4) Parmigiano Reggiano, B2-C2, grupy 3-4-osobowe, kompetencje: słuchanie, mówienie

Cel: powtórzenie nazw produktów spożywczych

Potrzebne materiały: piosenka Mamma Maria, reklama Parmigiano Reggiano wykorzystująca melodię z piosenki Mamma Maria $^{3}$

Przebieg ćwiczenia: Nauczyciel odsłuchuje z uczniami znaną włoską piosenkę Mamma Maria zespołu Ricchi e Poueri. Następnie jej wersję reklamującą parmezan. Zadaniem studentów jest wymyślenie nowych słów pod tę samą melodię, które reklamowałyby takie produkty jak na przykład: spaghetti al pomodoro (spaghetti z sosem pomidorowym), espresso, prosciutto crudo (włoską szynkę dojrzewającą) czy tiramisù. Na koniec każda z grup odczytuje lub odśpiewuje swoją wersję.

3 http://www.youtube.com/watch?v=KmZ28NIQPbM [dostęp 10.03.2014]. 


\subsection{Piłka nożna}

Martin Solly w swoim Podręczniku ksenofoba: Włochy [2011: 48] pisze, że „absolutnie najważniejszym sportem we Włoszech jest piłka nożna". I trudno się z nim nie zgodzić. We Włoszech naprawdę ciężko znaleźć osobę, która nie sympatyzowałaby z którąś ze znanych drużyn. Piłka nożna (wł. calcio) jest jak religia. Ucząc włoskiego, trudno więc zignorować tak istotny aspekt kultury mieszkańców Półwyspu Apenińskiego. Uczniowie nie muszą jednak wcale dobrze się na niej znać, by móc wykonać kilka prostych, stymulujących kreatywność ćwiczeń.

1) Intervista ad un calciatore (wywiad z piłkarzem), A1-C2, pary, kompetencje: pisanie, mówienie

Cel: ćwiczenie umiejętności zadawania pytań

Przebieg ćwiczenia: Nauczyciel przygotowuje odpowiednie do poziomu notki biograficzne trzech znanych włoskich piłkarzy (np. Francesco Totti, Mario Balotelli, Gianluigi Buffon) i prosi uczniów, żeby dobrali się w pary. Zadaniem każdej z par jest ułożenie pytań (i opcjonalnie - odpowiedzi) do wywiadu z wybranym piłkarzem. Na poziomie podstawowym pytania mogą być bardzo łatwe (np. „Gdzie teraz mieszkasz?” lub „Jaki jest twój ulubiony film?"), na poziomach zaawansowanych pytania muszą być trudniejsze i bardziej szczegółowe (dotyczyć mogą np. żartów na temat Tottiego czy córki Balotellego, której piłkarz nie chciał uznać).

2) Il televisore rotto (zepsuty telewizor), A1 + B1, indywidualnie/w parach, kompetencje: mówienie

Cel: powtórzenie słownictwa związanego z nazwami aktywności wykonywanych w czasie wolnym oraz czasowników (np. $w$ condizionale - trybie warunkowym lub imperativo - trybie rozkazującym)

Przebieg ćwiczenia: Nauczyciel prosi uczniów o wyobrażenie sobie sytuacji, $w$ której ich znajomy Włoch nie może obejrzeć niedzielnego meczu, ponieważ zepsuł mu się telewizor. Ich zadaniem jest wymyślenie dziesięciu aktywności, które pomogą włoskiemu koledze przetrwać trudne chwile. Przy prezentacji pomysłów 
na forum grupy, uczeń powinien używać np. trybu warunkowego (Potresti andare al cinema = Mógłbyś iść do kina) lub rozkazującego ( Va' al cinema = Idź do kina).

3) Commento sportivo (komentarz sportowy), B2-C2, indywidualne, kompetencje: słuchanie, mówienie

Cel: powtórzenie słownictwa związanego z piłką nożną (strzelać bramkę, zamieszanie pod bramką, bramkarz, obrońca, spalony, gol)

Potrzebne materiały: około 2-minutowe nagranie $z$ fragmentem meczu włoskiej ligi (dobrze, żeby na nagraniu widać było jak pada gol)

Przebieg ćwiczenia: Po wprowadzeniu słownictwa związanego z piłką nożną nauczyciel pokazuje uczniom fragment meczu bez dźwięku i prosi o zrobienie krótkiej notatki z tego, co zaobserwowali. Następnie prosi o wymyślenie komentarza do pokazanego fragmentu. W kolejnym etapie nauczyciel puszcza fragment meczu, a wybrani uczniowie po kolei go komentują. Nauczyciel podsumowuje zabawę i ocenia, czyj komentarz był najbardziej profesjonalny. Na koniec puszcza fragment meczu wraz z oryginalnym nagraniem.

\section{Zakończenie}

Umiejętność pobudzenia kreatywności uczniów powinna być istotna dla każdego nauczyciela, w tym dla lektora języka obcego. Dzięki kreatywności uczniowie nie tylko lepiej przyswajają wiedzę z zakresu języka i kultury, ale również dobrze się bawią i są bardziej zmotywowani. Połączenie metod klasycznych z ćwiczeniami stymulującymi kreatywność może okazać się niezawodną receptą na brak motywacji, znużenie czy zmęczenie. A wykorzystanie dodatkowo aspektów kulturowych może sprawić, że Włochy (lub inny kraj) okażą się być bliżej niż kiedykolwiek. 
Moda, kuchnia i piłka nożna: kreatywność i kultura w nauczaniu...

\section{Bibliografia}

Coppolaro-Nowell A. [2009], Jak żyć po włosku, Wydawnictwo JK, Łódź.

Dobrołowicz W. [1993], Psychika i bariery, WSiP, Warszawa.

Dobrołowicz W., Karwowski M. [2002], W stronę kreatywności, Wydawnictwo Akademii Pedagogiki Specjalnej im. Marii Grzegorzewskiej, Warszawa.

Gralewski J. [2006], Nauczycielskie koncepcje oceny wytworów twórczych, [w:] Dobrołowicz i in. (red.), Kreatywność kluczem do sukcesu w edukacji, Wszechnica Polska, Szkoła Wyższa Towarzystwa Wiedzy Powszechnej, Warszawa, s. 29-49.

Karwowski M. [2005], Konstelacja zdolności: typy inteligencji a kreatywność, Oficyna Wydawnicza „Impuls”, Kraków.

Komorowska H. [2005], Metodyka nauczania języków obcych, Fraszka Edukacyjna, Warszawa.

Łukasik B., Adamska-Staroń M., Piasecka M. [2009], Twórcze myślenie. Kreatywny student i nauczyciel, Akademia im. Jana Długosza w Częstochowie, Częstochowa.

Nęcka E. [2001], Psychologiatwórczości, Gdańskie Wydawnictwo Psychologiczne, Gdańsk.

Nęcka E. [1998], Trening twórczości. Podręcznik dla psychologów, pedagogów i nauczycieli, Oficyna Wydawnicza „Impuls”, Kraków.

Pallotti G. [2006], La seconda lingua, RCS Libri, Milano.

Solly M. [2011], Podręcznik ksenofoba: Włochy, Adamantan, Warszawa.

Starko A. J. [2010], Creativity in the classroom, Routledge, New York.

Szmidt K. J. [2006], Szkoła ciekawości i zachwytu - recz o koncepcji wychowania do twórczości Alane Jordan Starko, [w:] Dobrołowicz W. i in. (red.), Kreatywność kluczem do sukcesu w edukacji, Wszechnica Polska, Szkoła Wyższa Towarzystwa Wiedzy Powszechnej, Warszawa, s. 134-144.

Szmidt K. J. [2007], Pedagogika twórczości, Gdańskie Wydawnictwo Psychologiczne, Gdańsk.

Tokarski R. [2013], Światy za słowami, Wydawnictwo Uniwersytetu Marii Curie-Skłodowskiej, Lublin. 